\title{
o7. Özbek Türkçesinde mental fiiller
}

\section{Erdal AYDOĞMUŞı}

\begin{abstract}
APA: Aydoğmuş, E. (2021). Özbek Türkçesinde mental fiiller. RumeliDE Dil ve Edebiyat
\end{abstract} Araştırmaları Dergisi, (22), 135-151. DOI: 10.29000/rumelide.885545.

\section{$\ddot{\mathbf{O} z}$}

Köken olarak İngilizce bir terim olan ve Almanca, Fransızca gibi diller başta olmak üzere çoğu Avrupa dilinde yer alan "mental" sözcüğü Türkçede "akıl, zekâ, zihinsel, ruhsal" anlamında kullanılmaktadır. Buradan da anlaşılacağı üzere "mental” zihinle ilgili olan fiillerdir. Duygu, düşünce ve algılarla ilgili fiiller mental fiiller içerisinde yer almaktadır. Dolayısıyla mental fiiller zihinsel hareket sonucu ortaya çıkan fiillerden oluşmaktadır. Genel olarak tıp alanından psikoloji, psikanaliz, nöroloji, nöropsikoloji, çocuk gelişimi, gibi bilim dallarının ilgilendiği mental fiiller özellikle son zamanlarda dilbilimsel olarak incelense de bu alanda yapılan çalışmaların diğer disiplinlere göre az olduğu görülmektedir. Dilbilimsel açıdan çalışmaların az olduğu mental fiiller ile ilgili Türkiye Türkologları tarafından bazı Türk lehçelerindeki (Kazak, Kırgız, Türkmen vs.) mental fiiller konusu ele alınmış ve çeşitli çalışmalar yapılmıştır. Bu çalışmada Güneydoğu (Karluk) Türk lehçelerinden Özbek Türkçesindeki mental fiiller incelenmiştir. Mental fiillerinin belirlenmesinde Özbek Tilinin İzåhli Lugäti (1981), Özbek Tilinin İzåhli Frazeologik Lugäti (1978) ve Türkçe- Özbekçe Sözlük (2018) adlı eserlerden faydalanılmıştır. Adı geçen üç sözlükten tarama yoluyla tespit edilen Özbek Türkçesindeki mental fiiller; biliş fillleri, psikolojik durum fiilleri ve algılama fiilleri adlı başlıklar altında incelenmiştir. Yapılan çalışmayla Özbek Türkçesindeki mental fiillerin durumu hakkında bilgi verilmesi hedeflenmektedir.

Anahtar kelimeler: Özbek Türkçesi, mental fiil, bilişsel fiiller, psikolojik durum fiilleri, algılama fiilleri

\section{Mental verbs in Uzbek Turkish}

\begin{abstract}
The word "mental", originally an English term and found in most European languages, especially in languages such as German and French, is used in Turkish to mean "mind, intelligence, mental, spiritual". As can be understood from here, "mental" are verbs related to the mind. Verbs related to emotions, thoughts, and perceptions are included in mental verbs. Therefore, mental verbs are composed of verbs that occur as a result of mental movement. Although mental verbs, in which sciences such as psychology, psychoanalysis, neurology, neuropsychology, and child development are concerned, have been studied linguistically, it is seen that the studies in this field are less than other disciplines. The subject of mental verbs in some Turkish dialects (Kazakh, Kyrgyz, Turkmen, etc.), which has few linguistic studies, has been handled by Turcologists in Turkey and various studies have been carried out by researchers in terms of content. In this study, mental verbs in Uzbek Turkish from the Southeastern (Karluk) Turkish dialects were examined. In determining the mental verbs, works named Özbek Tilinin İzåhli Lugäti (1981), Özbek Tilinin İzåhli Frazeologik Lu
\end{abstract}

1 Dr. Öğr. Üyesi, Hoca Ahmet Yesevi Uluslararası Türk-Kazak Üniversitesi, Hazırlık Fakültesi, Türk Dili Bölümü, (Türkistan, Kazakistan); Ardahan Üniversitesi, İnsani Bilimler ve Edebiyat Fakültesi, Çağdaş Türk Lehçeleri ve Edebiyatları Bölümü (Ardahan, Türkiye), erdalaydogmus40@gmail.com, ORCID ID: oooo-ooo2-7642-7807 [Araştırma makalesi, Makale kaylt tarihi: 27.01.2021-kabul tarihi: 20.03.2021; DOI: 10.2900o/rumelide.885545.]

Adres | Address

RumeliDE Dil ve Edebiyat Araştırmaları Dergisi $\quad$ RumeliDE Journal of Language and Literature Studies Osmanağa Mahallesi, Mürver Çiçeği Sokak, No:14/8 Osmanağa Mahallesi, Mürver Çiçeği Sokak, No:14/8

Kadıköy - İSTANBUL / TÜRKIYE 34714 Kadıköy - ISTANBUL / TURKEY 34714 e-posta: editor@rumelide.com

e-mail: editor@rumelide.com

tel: +90 505 7958124, +90 2167730616 phone: +90 505 7958124, +90 2167730616 
Özäti (1978) and Turkish-Uzbek Dictionary (2018) were used. Mental verbs in Uzbek Turkish, determined by scanning from the mentioned three dictionaries, are examined under the headings of cognition verbs, psychological state verbs, and perception verbs . With this study, it is aimed to give information about the state of mental verbs in Uzbek Turkish.

Keywords: Uzbek Turkish, mental verb, cognition verbs, psychological state verbs, perception verbs

\section{Giriş}

Köken olarak İngilizce bir terim olan ve Almanca, Fransızca gibi diller başta olmak üzere çoğu Avrupa dilinde yer alan "mental" sözcüğü Türkçede "akıl, zekâ, zihinsel, ruhsal" anlamında kullanılmaktadır. Mental sözcügünün Türkçedeki karşllığı "zihinsel” sözcüğüyle karşılanmakta ve bilişsel dilbilimin içerisinde ele alınmaktadır. "Akademik alanda zihni konu edinen bilim dallarından biri olan bilişsel dilbilim içinde incelenen mental fiiller 21. yüzyll Türkiye Türkolojisinin ilgi gösterdiği konular arasında yer almaktadır." (Yıldız, 2019: 21).

Ayan ve Türkdil, mental süreçle ilgili olarak "İnsanın zihninde bir düzen içinde gerçekleşen oldukça karmaşık bir sistem vardır. Bu sistem bizim çevremizi ve olayları algılamamızı sağlamaktadır. Bu süreç mental süreçtir ve daha çok ruh bilimcilerin inceleme alanı içinde yer almıştır. Dil bilimciler her ne kadar ele almış olsa da daha çok kazanıma yönelik çalışmalar yapmışlardır." (Ayan ve Türkdil, 2015: 98) şeklinde bilgi vermektedirler.

Biray’a $(2006,310)$ göre mental fiiller; düşünmek ve hissetmekle, algı, duygu, duyu, davranış, sezgi, tanıma, hatırlama, idrak, değerlendirme ve açıklamayla ilgili fiillerdir.

Mental fiiller üzerine çeşitli çalışmaları bulunan Yıldız tarafından "Mental fiil nedir?" sorusuna cevap olarak şu bilgiler verilmiştir:

"Mental durum ve aktiviteleri karşılamaktadırlar. Semantiğinde fizikî bir hareket bulunmaz. Bazı fiiller isteğe bağlı, bazıları istem dışı oluşabilir. Geniş bir anlam yelpazesine sahiptir. Pek çok mental fiil, anlam bakımından kısmen aktif mental hareketleri karşılamaktadır: karar vermek, çalışmak vb. Bazı mental fiiller anlam bakımından diğerlerine nazaran daha fazla durum belirtirler: bir hareketten ziyade bir durumu tanımlarlar ve hoşlanmak, korkmak, nefret etmek ve tercih etmek gibi duygu ve davranışı gösteren pek çok fiilin yanı sıra inanmak, hatırlamak, anlamak gibi mental durumları da karşılarlar.” (Yıldız, 2018: 164).

Mental fiillerin sınıflandırılması ile ilgili olarak Yaylagül (2005: 24) tarafından yapılan sınıflandırma mevcuttur. Yaylagül, mental fiilleri dört gruba ayırmıştır: 1. Duyu fiilleri 2. Duygu fiilleri 3. Anı ve uslamlama fiilleri 4. Açıklama fiilleri.

Yegin'e (2019: 52) göre "Mental durumu ifade eden fiiller de zihinle ilgili fiillerdir. Bu fiiller semantik fiil sınıflandırılması çalışmalarında mental verbs "mental fiiller" olarak adlandırılmaktadır. Mental fiiller, algılarımızı, duygularımızı, idraklerimizi ifade eden fiillerdir.”

Mental fiillerin dilbilim ve anlambilim başta olmak üzere birçok alanla yakından bağlantısı olduğu söylenebilir. Bunların dışında sosyoloji ve psikoloji gibi bilim dallarıyla da ilişkisi bulunmaktadır. "Mental fiillerin insan zihninde gerçekleşen süreçleri anlatması ve insanın psikolojisini etkileyen her

\footnotetext{
\begin{tabular}{r|l} 
Adres & Address \\
RumeliDE Dil ve Edebiyat Araşttrmaları Dergisi & RumeliDE Journal of Language and Literature Studies
\end{tabular} Osmanağa Mahallesi, Mürver Çiçeği Sokak, No:14/8 Osmanağa Mahallesi, Mürver Çiçeği Sokak, No:14/8 Kadıköy - ISTANBUL / TÜRKIYE 34714 Kadıköy - ISTANBUL / TURKEY 34714 e-posta: editor@rumelide.com e-mail: editor@rumelide.com tel: +90 505 7958124, +90 2167730616 phone: +90 505 7958124, +90 2167730616
} 
türden değişkenin bu sürece dâhil olması bağlamında psikoloji ile iç içe geçmiş bir niteliği vardır. Sosyoloji ile olan bağı ise yine toplumsal hayatta insanların mental süreçlerinin kimi yerde sosyal bağlar ile ilgili olmasından kaynaklanmaktadır.” (Hirik, 2018: 22).

Mental fiillerin dilbiliminden başka diğer bilim dallarıyla olan ilişkisi konusuna Yıldız (2016: 64) da dikkat çekmektedir. "Mental fiiller, dilbiliminin yanı sıra psikoloji, psikanaliz, nöroloji, nöropsikoloji, çocuk gelişimi, eğitim bilimleri, reklamcılık vb. pek çok alanla da bağlantılı olarak disiplinlerarası çalışmalara hitap etmektedir.”

\section{Araştırma yöntemi ve sınırlılıklar}

Bu çalışmada yer alan Özbek Türkçesindeki mental fiillerin belirlenmesinde Özbek Tilinin İzåhli Lugäti (1981), Özbek Tilinin İzåhli Frazeologik Lugäti (1978) ve Türkçe- Özbekçe Sözlük (2018) adlı eserlerden faydalanılmıştır.

Yukarıda verilen eserler taranarak metal fiiller belirlenmiş ve konu başlıklarına göre sınıflandırılmıştır. Çalışmanın konusu olan fiillerin karşısına alıntı yapılan çalışmaların "Özbek Tilinin İzåhli Lugäti (ÖTİL), Özbek Tilinin İzåhli Frazeologik Lugäti (ÖTİFL), Türkçe-Özbekçe Sözlük (TÖS)” kısaltması yazılarak sayfa numarası gösterilmiştir.

\section{Mental fiiller üzerine yapılan çalışmalar}

Türkiye'de mental fiiller ile ilgili yapılan çalışmalar arasında tezler, makaleler, bildiriler ve kitap çalışması olduğu görülmektedir.

Mental fiil konusunu ele alan doktora tezleri: Kamchybekova (2010) "Kırgız Türkçesinde Duyu Fiilleri”, Şahin (2012) “Türkmen Türkçesinde Mental Fiiller”, Ylldız (2016) "Eski Uygurcada Mental Fiiller" ve Seçkin (2019) "Eski Türkçede Mental Fiiller" adlı çalışmalardır.

Mental fiillerin konu edildiği kitap çalışması ise Hirik (2018) tarafından kaleme alınan "Türkiye Türkçesinde Mental Fiiller” adlı kitaptır. Bu çalışma kitap hacminde Türkiye'de bugüne kadar yapılmış olan tek çalışmadır.

Tezler ve kitap çalışması haricinde makaleler de bulunmaktadır. Konuyla ilgili olarak, Yaylagül (2005, 2011) "Türk Runik Harfli Metinlerde Mental Fiiller", “Türkiye Türkçesindeki Duygu Fiilleri”, Biray (2006) "Kazak Şivesi ve Denizli Ağzında Kök Halindeki İdrak Fiillerinde Anlam Farklılaşmaları", Kamchybekova $(2011,2013)$ "Kırgız Türkçesinde Duyu Fiilleri”, "Duyu Fiillerinde Anlamsal Özellikler Üzerine”, Şahin (2012) "Mental Fiil Kavramı ve Türkmen Türkçesinde Mental Fiiller”, Ayan ve Türkdil (2014, 2015), "Anlam Bilimi Açısından Kazak Türkçesinde Görme Duyu Fiilleri”, "Kazak Türkçesinde Dokunma Duyu Fiilleri ve Anlam Zenginliği”, Yıldız (2017, 2018, 2019, 2020), "Eski Uygurcada Göz Fiilleri", “Atebetü'l-Hakayık'ta Algı Fiilleri”, "Eski Uygurcada Bellek Fiilleri”, "Eski Uygurcada Mental Fiiller Arası Geçişler Üzerine Notlar”, Hirik (2017) "Türkiye Türkçesi Duyu Fiillerinde Anlam ve Kelime Sıklığı İlişkisi", Alan ve Özeren (2018) "Kırgız Türkçesinde Mental Fiiller”, Yegin (2019) "Mental Fiil Kavramı ve Şeyyâd Hamza'nın Yūsuf u Zelihā Mesnevisinde Mental Fiiller" adlı başlıklarda mental fiilleri ele almışlardır.

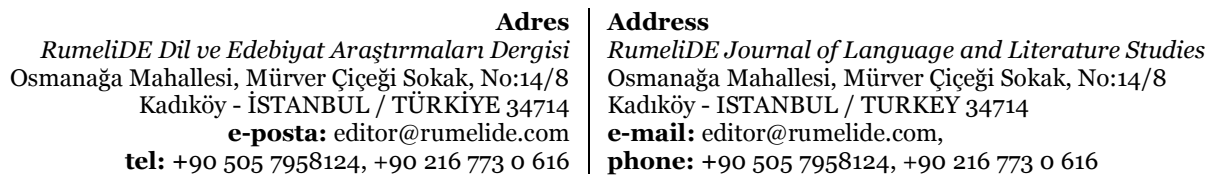




\section{1. Özbek Türkçesinde mental fiiller}

\subsection{Bilișsel fiiller}

Mental fiillerin bir kolu olan bilişsel fiiller zihinsel durumla ilgilidir. "Mental sürecin işlem basamağında çeşitli zihinsel faaliyetler gerçekleşmektedir. $\mathrm{Bu}$ zihinsel faaliyetleri ifade eden hareketler, dilde farklı fiillerle karşılık bulmaktadır. Zihinsel işlemlerin ifade edildiği bu tür fiiller bilişsel fiil olarak adlandırılmaktadır.” (Hirik, 2018: 56).

Mental fiiller ile ilgili yapılan çalışmalarda bilişsel fiil teriminin yanı sıra "biliş fiilleri" ya da "idrak fiilleri” terimleri kullanılmaktadır. "Mental fiillerin bir grubunu oluşturan biliş fiilleri 'cognitive verb', bazı araştırmacılar tarafından 'idrak fiilleri’ şeklinde adlandırılmıştır.” (Alan ve Özeren, 2018: 206).

Bilişsel fiiller özellikle çocukların zihinsel dünyasıyla yakından ilgili olup çocukların zihinsel dünyasını etraflıca tanımlamaktadır. Bilişsel fiiller "Çocukların zihinsel dünyalarının bütün yönlerini tanımlar. Çocuklar; denetleme, dönüştürme, kurma, düzeltme ve iç mental durumlarının anlamını açıklamak için kognitif fiilleri kullanabilir. Bu sebeple, kognitif fiillerin kazanımını anlamak araştırmacılara zihin gelişimi çalışmalarında ışık tutabilir.” (Şahin, 2012:52).

Yaylagül'ün (2005) çalışmasında bilişsel fiilleri "anı ve uslanma fiilleri” başlığında ele alınmıştır. Türk Runik harfli metinlerden elde edilen; bil- "bilmek", $u$ - "muktedir olmak, yapabilmek, edebilmek", untt"unutmak", sakın- "düşünmek, kaygılanmak”, ö- "düşünmek, akıl etmek, bilmek, anımsamak”, ayla"anlamak, tanımak", (a)r- "aldatmak", y(a)y(l)l- "yanılmak", az- "şaşırmak, yoldan çıkmak”, kịşür"kışkırtmak, aleyhe tahrik etmek" fiilleri bu grup içinde değerlendirilmiştir.

Biray’’n (2007) bilişsel fiiller için "idrak fiilleri” terimini kullandığı görülmektedir. Biray çalışmasında idrak fiillerini "duyu”, "duygu”, "hafıza”, "açıklama” başlıklarında incelemiştir.

Bilişsel fiilleri, Şahin (2012) “idrak filleri”, Alan ve Özeren’in (2017) ise "biliş fiilleri” başlı̆̆ı altında, anlama ifade eden fiiller, düşünme ifade eden fiiller, niyet-istek- arzu ifade eden fiiller, hayal ifade eden fiiller, tahmin ifade eden fiiller, unutma ifade eden filler, hattrlama ifade eden fiiller olarak ele aldıkları görülmektedir.

Taramada tespit edilen bilişsel filler Şahin ve Alan ve Özeren'in çalışmalarındaki gibi anlama ifade eden fiiller, düşünme ifade eden fiiller, niyet-istek- arzu ifade eden fiiller, hayal ifade eden fiiller, tahmin ifade eden fiiller, unutma ifade eden fiiller, hatırlama ifade eden fiiller olmak üzere yedi alt başlıkta verilmiştir.

\subsubsection{Anlama ifade eden fiiller}

Anlama ifade eden fiiller ile ilgili olarak toplam 16 fiil tespit edilmiştir. Fiillerin tespit edilmesinde faydalanılan kaynak eserler arasında en çok fiil Türkçe- Özbekçe Sözlükten belirlenmiştir.

angla- "anlamak" (TÖS, s. 40), tuşun- "anlamak" (TÖS, s. 40), idrok et- "anlamak" (TÖS, s. 40), fahmla- "anlamak" (TÖS, s. 41), anglaşil- "anlaşllmak" (TÖS, s. 41), tusunil- "anlaşlmak" (TÖS, s. 41), fahmlanil- "anlaşılmak" (TÖS, s. 41), mahkam uşla- "kavramak" (TÖS, s. 319), qamra"kavramak" (TÖS, s. 319), tuşunib yet- "kavramak" (TÖS, s. 319), häyåldän keçir- "düşünmek, idrak etmek, aklından geçirmek" (ÖTİFL, s. 245), közini åç- "iyiyi kötüyü ayırt etmek, uyanık olmak"

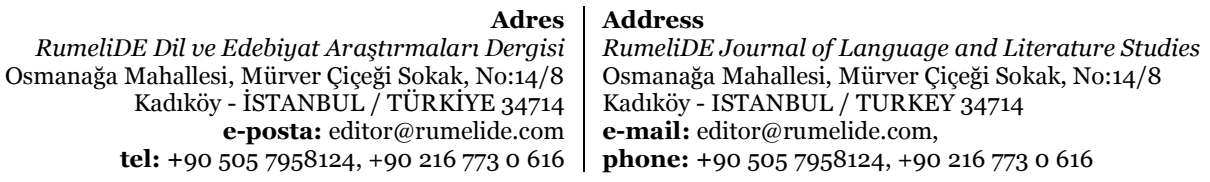


(ÖTIFL, s. 139), äqlı yet- "idrak etmek, anlamak, bilmek" (ÖTíFL, s. 29), åq bilän qårani acrat"iyiyi kötüyü ayırt edebilmek, faydalı ya da faydasız olduğunu anlamak" (ÖTíFL, s. 197, åq bilän qårani bil- "iyiyi kötüyü ayırt edebilmek, faydalı ya da faydasız olduğunu anlamak" (ÖTíFL, s. 197), åq bilän qårani tani- "iyiyi kötüyü ayırt edebilmek, faydalı ya da faydasız olduğunu anlamak" (ÖTİFL, s. 197).

\subsubsection{Düşünme ifade eden fiiller}

Bilişsel fiiller arasında yer alan düşünme ifade eden fiiller ile ilgili 15 fiile ulaşılmıştır. Tespit edilen fillerin çoğu “Özbek Tilinin İzåhli Frazeologik Lugäti” adlı eserden alınmıştır.

o‘yla- "düşünmek" (TÖS, s. 172), fikrla- "düşünmek" TÖS, s. 172), muhokama qil- "düşünmek" TÖS, s. 172), fahmla- "düşünmek” TÖS, s. 172), qaygulan- "düşünmek” TÖS, s. 172), häyålgä çöm"hayal âlemine dalmak, çok düşünceli halde olmak" (ÖTİFL, s. 245), köziniy åldigä kel"hatırlamak" (ÖTIFL, s. 146), özidän ket- "bayılmak, kendini kaybetmek"(ÖTİFL, s. 281), özig̈ä kel“1. aylmak. 2. anlamak, aklı başına gelmek" (ÖTíFL, s. 280), båş(i)ġä kel- "düşünmek, idrak etmek" (ÖTIFL:181), båşi şiş- "düşünmekten yorulmak" (ÖTİFL, s. 53), båşini qåtir- "uzun uzun düşünmek, kesin bir sonuca ulaşamamak" (ÖTiFL, s. 52), köylidän keçir- "bir süre düşünmek" (ÖTİFL, s.161), köyligä kel- “düşünmek, aklından geçirmek” (ÖTIL, s. 458).

\subsubsection{Niyet, istek ve arzu ifade eden fiiller}

Bu grupta toplam 13 fiil yer almaktadır. Fiillerin çoğu “Özbek Tilinin İzåhli Lugäti” adlı sözlükten tespit edilmiştir.

årziq- "şiddetle arzu etmek, erişme isteğiyle yanmak" (ÖTíL, s. 136), årzulä- "arzulamak, arzu etmek, heveslenmek, özenmek" (ÖTILL, s. 136), ista- "istemek" (TÖS, s. 290), ihtiyor et- "istemek" (TÖS, s. 290), xohla- "istemek" (TÖS, s. 290), årzu- hävas kör- "çocuklarını büyütüp evlendirip onların tüm mutlu günlerini görmek istemek" (ÖTİL, s. 137), orzu qil- "arzulamak" (TÖS, s. 49), tilä- "dilemek, istemek" (ÖTILL, s. 94), åyåq tirä- "kendi düşüncesini gerçekleşmesini inatla talep etmek, diretmek" (ÖTIFL, s. 190), köyil åvlä- "kendine çekmeye, tavlamaya çalışmak" (ÖTIFL, s. 164), ikki åyågini bir etikkä soq- "amacının bir an önce gerçekleşmesi için birini sıkıştırmak" (ÖTíFL, s. 111), köygüllä- "gönülden istemek, istemek" (ÖTİL, s. 460), täläb qil- "şiddetle istemek, talep etmek" (ÖTíL, s. 647).

\subsubsection{Hayal ifade eden fiiller}

Hayal ifade eden fiiller arasında 6 fiil tespit edilmiş olup hepsi “Özbek Tilinin İzåhli Lugäti” adlı sözlükten alınmıştır.

häyålgä båt- "düşünmek, düşüncelere dalmak” (ÖTİL, s. 373), häyålgä tål- "düşünmek, düşüncelere dalmak" (ÖTİL, s. 373), häyålgä çöm- "düşünmek, düşüncelere dalmak” (ÖTİL, s. 373), häyål sur“düşünmek, düşüncelere dalmak” (ÖTíL, s. 373), häyållän- "hayal etmek, düşünmek” (ÖTíL, s. 373), häyålsira- "hayal etmek, hayal âlemine dalmak, düşünmek" (ÖTíL, s. 373).

\begin{tabular}{r|l} 
Adres & Address \\
RumeliDE Dil ve Edebiyat Araşttrmaları Dergisi & RumeliDE Journal of Language and Literature Studies \\
Osmanağa Mahallesi, Mürver Çiçeği Sokak, No:14/8 & Osmanağa Mahallesi, Mürver Çiçeği Sokak, No:14/8 \\
Kadıköy - İSTANBUL / TÜRKIYE 34714 & Kadıköy - ISTANBUL / TURKEY 34714 \\
e-posta: editor@rumelide.com & $\begin{array}{l}\text { e-mail: editor@rumelide.com, } \\
\text { phone: +90 505 7958124, +90 } 216773 \text { o } 616\end{array}$
\end{tabular}




\subsubsection{Tahmin ifade eden fiiller}

Tahmin ifade eden fiiller arasında 3 fiil tespit edilmiştir. Bu 3 fiilin hepsi “Özbek Tilinin İzåhli Lugäti” adlı eserden alınmıştır.

tähminlä- "tahmin sonucu hüküm çlkarmak, tahmin etmek, tahminen" (ÖTİL, s. 16), çämälä"tahmin etmek" (ÖTİL, s. 452), mölcällä "tahmin etmek, tahminde bulunmak" (ÖTIL, s. 668).

\subsubsection{Unutma ifade eden fiiller}

Unutma ifade eden fiiller adlı başlıkta toplam 10 fiil yer almaktadır. Bu başlık içerisinde bulunan fiillerin çoğu “Özbek Tilinin İzåhli Frazeologik Lugäti” sözlüğünden tespit edilmiştir.

unut- "unutmak" (TÖS, s. 600), unuttira al- "unutturabilmek" (TÖS, s. 600), unuttir"unutturmak" (TÖS, s. 600), unutil- "unutulmak" (TÖS, s. 600), esidän çiqar- "unutmak" (ÖTİFL, s. 257), esidän çiq- "unutmak" (ÖTİFL, s. 257), yådidän kötär- "unutmak" (ÖTİFL, s. 257), yådidän kötäril- "unutmak" (ÖTİFL, s. 257), häyålidän kötäril- "aklından çıkarmak" (ÖTİFL, s. 374), håtiridän çiq- "unutmak” (ÖTİFL, s. 248).

\subsubsection{Hatırlama ifade eden fiiller}

Bilişsel fiillerin son başlığı olan hatırlatma ifaden fiiller ile ilgili 10 fiile ulaşılmıştır. Tespit edilen fiillerin çoğu Özbek Tilinin İzåhli Frazeologik Lugäti” adlı eserden alınmıştır.

xotirla- "hatırlamak" (TÖS, s. 252), esla- "hatırlamak" (TÖS, s. 252), tilinin uçida tur- "bildiği halde o anda hatırlayamamak, söyleyememek" (ÖTADS, s.119), köziniy åldigä kel- "hatırlamak" (ÖTİFL, s. 146), esgä kel- "hatırlamak" (ÖTİFL, s. 365), esgä keltir- "hatırlamak" (ÖTİFL, s. 365), esgä ål- "hatırlamak" (ÖTİFL, s. 365), esgä tüşir- "hatırlamak" (ÖTİFL, s. 365), yådgä sål"hatırlamak" (ÖTİFL, s. 86), yådgä tüş- "hatırlamak" (ÖTİFL, s. 86).

\subsection{Psikolojik durum fiilleri}

Mental fiiller arasında yer alan psikolojik durum fiilleri bireylerin iç dünyalarında yaşadıkları olumlu ya da olumsuz durumlardır.

Çeçen'e (2002: 165) göre "Duygu genel anlamda bireyle ilişkili öznel yaşantıları, birey için önemli olan olaylarla ilişkili olarak bireyin neler yapabileceğini, bağlamın değerlendirmesini içeren, tanımlanabilir dönemleri olan bir süreç olarak ifade edilebilir."

İnsanoğlunun günlük hayatta başından geçen olayların ve durumların sonucu olarak insanların iç dünyasında birtakım etkiler meydana gelmektedir. Böylece psikolojik durum fiilleri ortaya çımmaktadır. Bu filler mental fiiller içerisinde psikolojik durum ya da duygu fiilleri olarak adlandırılmaktadır. "Kişinin yaşadıklarına ve çevredeki uyarıcılara paralel olarak zihin alanında olumlu veya olumsuz duygu halleri oluşabilmektedir. Bu duygu halleri, psikolojik durum fiilleri olarak belirmektedir." (Alan ve Özeren, 2018: 209).

Mental fiillerin gruplandırılmasında birinci grupta yer alan biliş fiillerinden sonra ikinci grupta ise duygu fiilleri yani psikolojik durum filleri yer almaktadır.

\begin{tabular}{|c|c|}
\hline Adres & Idd \\
\hline $\operatorname{arl} D$ & DE Jou \\
\hline Mahallesi, & Osmanağa Mahallesi, Mürver Çiçeği Sokak, No:14/8 \\
\hline Kadıköy - & Kadıköy - ISTANBUL / TURKEY 34714 \\
\hline $\begin{array}{r}\text { e-posta: editor@rumelide.com } \\
\text { tel: }+905057958124,+902167730616\end{array}$ & $\begin{array}{l}\text { e-mail: editor@rumelide.com, } \\
\text { phone: +90 505 7958124, +90 } 2167730616\end{array}$ \\
\hline
\end{tabular}


Yaylagül (2011:101) tarafından duygu fiilleri ile ilgili olarak "Duygusal tepki fiilleri bir etkiye karşı ortaya çıkarlar, dolayısıyla etkiye karşı verilmiş bu tepkiler bir çeşit yanıt niteliğindedir. Başka bir deyişle kişinin duygusal yanıtıdır. Bundan dolayı duygusal yanıt fiili diye de adlandırılır." denmektedir.

Psikolojik durum fiilleri ya da duygu fiilleri olarak mental fiiller içerisinde incelenen fiiller ile ilgili olarak Şahin (2012: 55) tarafından "Mental sürecin çıktılarından biri de duygulardır. Olayların, durumların, yaşantıların insanların iç dünyasında, zihninde uyandırdığı izlenim ve bunun duygularla ilgili çıktıları duygu fiilleridir.” şeklinde bilgi verilmektedir.

Olumlu ya da olumsuz olmak üzere insanoğlunun duygularını ifade etmek için kullanmakta olduğu psikolojik durum fiilleri yeryüzünde konuşulmakta olan tüm dillerde bulunmaktadır. Duygu fiillerini olumlu ve olumsuz fiiller şeklinde ikiye ayırmak mümkündür. "Olumlu duygu fiilleri söz konusu varlığa duyulan olumlu duyguları ifade ederken, olumsuz duygu fiilleri söz konusu varlığa duyulan olumsuz duyguları ifade eder." (Yaylagül, 2005: 20).

Şahin (2012) çalışmasında duygu fiillerini, kuşku ve şüphe ifade eden fiiller, sevgi ifade eden fiiller, öfkelenme ifade eden fiiller, kaygl, endişe, telaş ifade eden fiiller, korku ifade eden fiiller, şaşırma ifade eden fiiller, üzüntü ifade eden fiiller, utanma, çekinme ifade eden fiiller, pişmanlk ifade eden fiiller başlı̆̆ında incelemiştir.

"Psikolojik durum fiilleri” adlı başlık altında duygu fiillerini inceleyen Alan ve Özeren (2018) de duygu fiillerini Şahin’in çalışmasındaki başlıklardaki gibi incelemiştir.

Yaylagül (2005) çalışmasında Türk Runik harfli metinlerde duyguları gösteren çok sayıda fiilin bulunduğundan bahsetmektedir. Yaylagül duygu fillerini bütünsel davranış tepki fiilleri (ürk-, kork-, korkut-, kız-, öfkelen-), olumsuz duygu fiilleri ve olumlu duygu filleri adlı başlıklarda ele almıştır.

Taramada tespit edilen psikolojik durum fiilleri kuşku ve şüphe ifade eden fiiller, sevgi ifade eden fiiller, mutluluk ifade eden fiiller öfkelenme ifade eden fiiller, kaygı endişe ve telaş ifade eden fiiller, korku ifade eden fiiller, şaşırma ifade eden fiiller, üzüntü ifade eden fiiller, utanma ifade eden fiiller, pişmanlık ifade eden fiiller, sakinleşme ifade eden fiiller olmak üzere on bir alt başlıkta verilmiştir.

\subsubsection{Kuşku ve şüphe ifade eden fiiller}

Tarama sonucunda "kuşku ve şüphe ifade eden fiiller" başlığında beş tane psikolojik durum fiili tespit edilmiştir.

şubhalan- "şüphelenmek" (TÖS, s. 548), täräddutlän- "tereddüt etmek" (ÖTíL, s. 673), gumån qil- "şüphelenmek" (ÖTİL, s. 524), gumånlan- "birinden veya bir şeyden şüphelenmek" (ÖTİL, s. 524), gumånsirä- "birinden veya bir şeyden biraz şüphelenmek” (ÖTíL, s. 524).

\subsubsection{Sevgi ifade eden fiiller}

Bu başlıkta incelenen psikolojik durum fiilleri arasında yer alan toplam 9 fiil tespit edilmiştir. Tespit edilen fillerden "sevmek" / "âşık olmak" fiilinin birden fazla şekilde dile getirildiği dikkat çekmektedir.

sev- "sevmek" (TÖS, s. 507), yåqtir- "sevmek" (TÖS, s. 507), yahşi kör- "sevmek" (TÖS, s. 507), köyil ber- "sevmek, âşık olmak" (ÖTİFL, s. 153), köyil båg̊lä- "sevmek, âşık olmak" (ÖTİFL, s. 153),

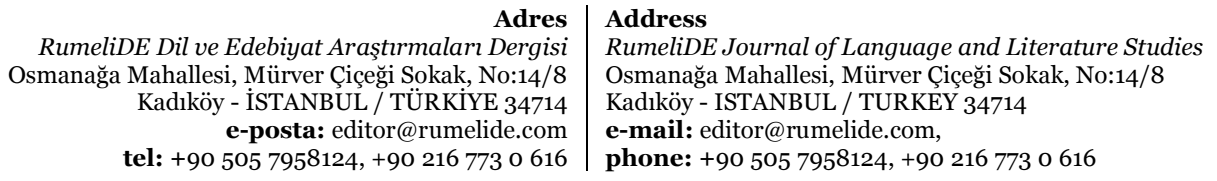


köyil qoy- "sevmek, gönül bağlamak, âşık olmak. (ÖTİFL, s. 154), mehr qoy- "gönülden sevmek" (ÖTiFL, s. 180), muhabbat qoy- "sevmek, âşık olmak" (ÖTíFL, s. 180), huş kör- "beğenmek, hoşuna gitmek, sevmek” (ÖTİFL, s. 248).

\subsubsection{Mutluluk ifade eden fiiller}

Günlük hayatta insanoğlu bazen mutlu bazen mutsuz anlar yaşayabilmektedir. İncelenen sözlüklerden Özbek Türkçesinde mutluluğu ifade eden toplam 6 fiil ile karşılaşılmıştır.

båşi äylän- "1. başı dönmek, kendinden geçer gibi olmak. 2. mutluluktan sarhoş duruma gelmek" (ÖTIFL, s: 46), båşi kökkä yet- "çok sevinmek, mutlu olmak" (ÖTİFL, s. 49), köksi kötäril- "mutlu olmak, sevinmek, kıvanmak" (ÖTİFL, s. 152), åġzi qulågigä yet- "çok sevinmek, mutlu olmak" (ÖTİFL, s. 203), terisigä sig̉may ket- "çok sevinmek" (ÖTİFL, s. 226), içägini uz- "kahkaha atmak" (ÖTİFL, s. 115).

\subsection{4. Öfkelenme ifade eden fiiller}

Öfkelenme ifade eden fiiller adlı başlıkta toplam 9 fiil bulunmaktadır. Bunların içinde "kızmak" fiilinin 3 farklı şeklinin olduğu görülmektedir.

qizi- "kızmak" (TÖS, s. 335), qiziş- "kızmak" (TÖS, s. 335), qahrlän- "hiddetlenmek" (ÖTİL, s. 272), asabiyläş- "sinirlenmek" (ÖTiL, s. 104), hirslän- "hırslanmak" (TÖS, s. 261), aqlini yoqåt- "aklını kaybetmek, delirmek" (ÖTİFL, s. 30), qåni qäyna- "sinirlenmek, öfkelenmek" (ÖTİFL, s. 291), zähär såç- "öfkeyle can yakarak konuşmak" (ÖTİFL, s. 106), tanbeh ber- "kızmak” (ÖTİFL, s. 221).

\subsubsection{Kaygı, endişe ve telaş ifade eden fiiller}

Kaygı, endişe ve telaş insanoğlunun hayatının bir parçasıdır diyebiliriz. Bu psikolojik durum ile ilgili olarak Özbek Türkçesinde bulunan 7 fiil tespit edilmiştir.

taloshlan- "telaşlanmak" (TÖS, s. 568), sarosimaga tush-"paniklemek" (TÖS, s. 446), esankirat"paniklemek" (TÖS, s. 446), garangsi- "paniklemek" (TÖS, s. 446), dovdira- "paniklemek" (TÖS, s. 446), qayg்ur- "tasalanmak” (ÖTİL, s. 223), gam ye- "kaygılanmak” (ÖTİFL, s. 305).

\subsubsection{Korku ifade eden fiiller}

Korku ifade eden fiiller başlığında 12 fiil yer almaktadır. Fiillerin tamamı Türkçe- Özbekçe Sözlükten tespit edilmiştir.

titrä- "ürpermek" (ÖTİL, s. 117), irkil- "irkilmek” (TÖS, s. 288), seskan- "irkilmek" (TÖS, s. 288), hurk- "irkilmek" (TÖS, s. 288), choçi- "irkilmek" (TÖS, s. 288), titra- "titremek" (TÖS, s. 581), qaltira- "titremek" (TÖS, s. 581), hurkaklaş- "ürkekleşmek" (TÖS, s. 611), hurk- "ürkmek" (TÖS, s. 611), çåçi- "ürkmek" (TÖS, s. 611), qårq- "ürkmek” (TÖS, s. 611), garangsi- "ürkmek” (TÖS, s. 611).

\subsection{7. Şaşırma ifade eden fiiller}

Psikolojik durum fiilleri arasında bulunan şaşırma ifade eden filler ile ilgili 7 fiil tespit edilmiştir.

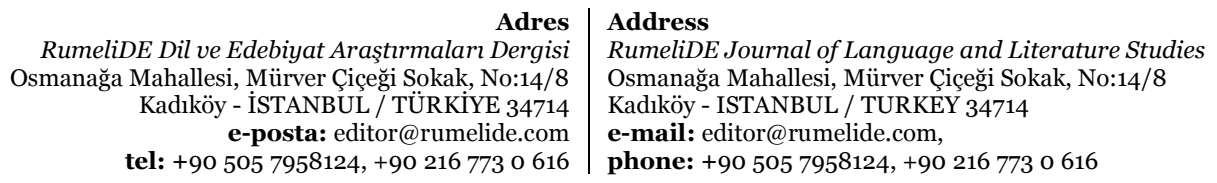


şoşib qol- "şaşırmak" (TÖS, s. 541), ozini yoqotib qoy- "şaşırmak" (TÖS, s. 541), gangib qol"şaşırmak" (TÖS, s. 541), dovdira- "şaşırmak" (TÖS, s. 541), häyrån qål- "şaşırmak, hayret etmek" (ÖTİFL, s. 307), häyråtdä qål- "şaşırmak, hayret etmek" (ÖTİFL, s. 307), yöqasini uşla- "şaşırmak, hayret etmek" (ÖTİFL, s. 89).

\subsection{8. Üzüntü ifade eden fiiller}

Özbek Türkçesinde üzüntü ifade eden fiilleri ile ilgili olarak taranan eserlerden toplam 24 fiile ulaşılmıştır.

ranji- "üzülmek" (TÖS, s. 614), hafa bol- "üzülmek” (TÖS, s. 614), qayg்ulän- "kederlenmek” (ÖTİL, s. 223), ränji- "acı çekmek, kırılmak" (ÖTİL, s. 350), häfä qil- "üzmek, acı vermek" (ÖTíL, s. 391), azåb çek- "zorlanmak, sıkıntı çekmek" (ÖTİFL, s. 25), azåbini tårt- "zorlanmak, sıkıntı çekmek" (ÖTİFL, s. 25), äläm çek- "zorlanmak, sıkıntı çekmek" (ÖTİFL, s. 25), båşidä yång̊åq çaq- "acı çekmek, zorlanmak" (ÖTİFL, s. 47), båşidä dänäk çaq- "acı çekmek, zorlanmak” (ÖTİFL, s. 47), båşidä tåş çaq- "acı çekmek, zorlanmak" (ÖTíFL, s. 47), miyäsidä dänäk çaq- "acı çekmek, zorlanmak” (ÖTİFL, s. 47), bäğrini ez- "canı sıkılmak, üzülmek” (ÖTİFL, s. 29), cånig̈ä teg"yorulmak, usanmak, bıkmak" (ÖTIFL, s. 96), cånidän bezår bol- "dayanacak gücü kalmamak, sıkılmak" (ÖTİFL, s. 96), içini ye- "acı çekmek, üzülmek, derdini kimseye söyleyemeyip içi ezilmek" (ÖTİFL, s. 118), käyfi bozul- "morali bozulmak, üzülmek, canı sıkılmak", (ÖTİFL, s. 125), yürägi ezil- "acı çekmek, üzülmek” (ÖTíFL, s. 272), öz yågigä özi kåvuril- "acı çekmek, üzülmek, derdini anlatamamak" (ÖTİFL: 279), cåni äçi- "birine acımak, üzülmek" (ÖTİFL, s. 95), näri- berigä bår“darılmak, küsmek" (ÖTİFL, s. 184), özini özi yeb qoy- "çok sıkılmak" (ÖTİFL, s. 281), qån yut“çok sıkılmak" (ÖTİFL, s. 291), gazabgä kel- "sinirlenmek” (ÖTIFL, s. 304).

\subsubsection{Utanma ifade eden fiiller}

Utanma ifade eden fiiller ile ilgili olarak incelenen eserlerden 10 fiile rastlanmıştır.

båşini häm qil- "rezil olmak" (ÖTİFL, s. 51), tårtin- "utanmak" (ÖTíL, s. 153), uyal- "utanmak" (TÖS, s. 601), uyat- andisha hissi tuy- "utanmak" (TÖS, s. 601) andişa hissi tuy- "utanmak" (TÖS, s. 601), bir/üç pul bol- "zor duruma düşmek, rezil olmak" (ÖTİFL, s. 42), yergä kirip ket"utançtan, çok üzüntü duymak, sıkılmak" (ÖTİFL, s. 81), yergä qarä- "utancından kafasını kaldıramayacak hale gelmek" (ÖTİFL, s. 81), yuzini yergä qarät- "rezil olmak" (ÖTİFL, s. 264), izzä tårt- "utanmak" (ÖTIFL, s. 110).

\subsubsection{Pişmanlık ifade eden fiiller}

Taranan eserlerden elde edilen verilere göre pişmanlık ifade eden filler ile ilgili 3 fiil tespit edilmiştir.

içini kemir- "pişmanlık duymak" (ÖTíFL, s. 116), puşäymån bol- "pişman olmak, pişmanlık duymak" (ÖTİL, s. 325), puşäymån qil- "pişman etmek” (ÖTİL, s. 325).

\subsubsection{Sakinleşme ifade eden fiiller}

Sakinleşme ifade eden filler ile ilgili olarak taranan eserlerden 5 fiil ile karşılaşılmıştır.

\begin{tabular}{r|l} 
Adres & Address \\
RumeliDE Dil ve Edebiyat Araştırmalar Dergisi & RumeliDE Journal of Language and Literature Studies \\
Osmanağa Mahallesi, Mürver Çiçeği Sokak, No:14/8 & Osmanağa Mahallesi, Mürver Çiçeği Sokak, No:14/8 \\
Kadıköy - İSTANBUL / TÜRKIYE 34714 & Kadıköy - ISTANBUL / TURKEY 34714 \\
e-posta: editor@rumelide.com & e-mail: editor@rumelide.com, \\
phone: +90 505 7958124, +90 2167730616
\end{tabular}


açigiidän tüş- "sakinleşmek, kendine gelmek" (ÖTİFL, s. 28), cählidän tüş- "sakinleşmek, kendine gelmek" (ÖTIFL, s. 28), zähridän tüş- "sakinleşmek, kendine gelmek” (ÖTİFL, s. 28), gazäbidän tüş- "sakinleşmek, kendine gelmek" (ÖTİFL, s. 28), zähr tüş- "sakinleşmek, kendine gelmek" (ÖTİFL, s. 106).

\subsection{Algılama ifade eden fiiller}

Algılama fiilleri aynı zamanda duyu fiilleri olarak da adlandırılmaktadır. Beş duyu organımız olan göz, kulak, dil, burun ve el ile algılama işlemi gerçekleştirilir. Göz ile somut nesneleri görür, kulak ile sesleri işitir, dil ile tat, burun ile kokuları alır, el ile cisimlere dokunup onları algılarız.

Kamchbekova (2011: 88- 89) algılama eylemi ile ilgili olarak algılama eyleminin görevi çeşitli duyulardan gelen bilgileri beyindeki dil merkezlerine ulaştırmaktır. Dolayısıyla dil süreçlerinin işlevi algılamaktan başlamaktadır ve her türlü insan faaliyetinin merkezine giden yol algılamaktan geçtiğini söylemektedir.

Yaylagül'e (2005: 24) göre algılama fiilleri, mental etkinliğin gerçekleşmesi için gerekli olan girdilerin toplanması işlerini gösterir. Dolayısıyla idrak etme sürecinin (cognitive process) başlatıcılarıdır.

Mental fiillerin diğer bilim dallarıyla olan ilişkisi algılama fiillerinin dilbilim alanından başka diğer bilim dallarına da araştırma konusu olduğu bilinmektedir. Bununla ilgili olarak Kamchybekova (2011: 88) tarafından algılama fiillerinin dilbilimden çok zihinsel süreçlerle ilişkili olmasından dolayı ruh bilim ve zihinsel felsefe alanında daha çok ele alındığı vurgulanmaktadır.

Algılama fiilleri ile özellikle çocukların zihinsel dünyası arasında bir bă̆ vardır. Savaş (2012: 52) algılama fiillerinin, çocukların zihinsel dünyalarının bütün yönlerini tanımladığını, çocukların; denetleme, dönüştürme, kurma, düzeltme ve iç mental durumlarının anlamını açıklamak için algılama fiillerini kullanabileceklerini, bu sebeple, algılama fiillerinin kazanımını anlamak araştırmacılara zihin gelişimi çalışmalarında ışık tutabileceğini söylemektedir.

$\mathrm{Bu}$ çalışmada, taramada tespit edilen algılama ifade eden fiilleri, görme ile ilgili algılama fiilleri, işitme ile ilgili algzlama filleri, tatma ile ilgili algnlama fiilleri, koklama ile ilgili algzlama filleri, dokunma ile ilgili algılama fiilleri olmak üzere beş alt başlık halinde verilmiştir:

\subsubsection{Görme ile ilgili algılama fiilleri}

Algılama ifade eden fiiller başlığı içerisinde yer alan görme ile ilgili algılama fiilleri ile ilgili olarak 15 fiil belirlenmiştir. Bu fiillerin çoğu “Özbek Tilinin İzåhli Lugäti” adlı sözlükten tespit edilmiştir.

boq- "bakmak" (TÖS, s. 66), qara- "bakmak" (TÖS, s. 66), qarä- "bir şeye veya bir kimseye bakmak için gözünü o tarafa yönlendirmek, bakmak" (ÖTíL, s. 243, küzät- "bir şeyi teyit etmek amacıyla gözetlemek" (ÖTİL, s. 420, köz q1rı bilän qarä- "göz ucuyla bakmak" (ÖTíL, s. 444), köz täşlä"bakmak, dikkatlice bakmak" (ÖTİL, s. 444), köz tik- "gözünü kırpmadan bakmak, hasretle bakmak, bakmak" (ÖTİL, s. 444), köz uriştir- "bakışmak" (ÖTİL, s. 444), köz yügirtir- "hızlı bir şekilde bakmak, göz atmak" (ÖTiL, s. 444), közi tüş- "görmek, şahit olmak" (ÖTİL, s. 445), köz teg- "nazar değmek, uğursuzluk getirmek" (ÖTİFL, s. 148), köz süz- "dikkat çekmek amacıyla nazlı, anlamlı bakmak” (ÖTİFL, s. 148), közdän keçir- "bakmak, incelemek” (ÖTIFL, s. 133), közdän ötkäz-

\footnotetext{
Adres $\mid$ Address

RumeliDE Dil ve Edebiyat Araşttrmaları Dergisi $\quad$ RumeliDE Journal of Language and Literature Studies Osmanağa Mahallesi, Mürver Çiçeği Sokak, No:14/8 Osmană̆a Mahallesi, Mürver Çiçeği Sokak, No:14/8 Kadıköy - ISTANBUL / TÜRKIYE 34714 Kadıköy - ISTANBUL / TURKEY 34714 e-posta: editor@rumelide.com e-mail: editor@rumelide.com tel: +90 505 7958124, +90 2167730616 phone: +90 505 7958124, +90 2167730616
} 
"bakmak, incelemek" (ÖTİFL, s. 133), közi qamäş- "1. 1şıtan bakamamak. 2. çok etkilenmek." (ÖTİFL, s. 143).

\subsection{2. İşitme ile ilgili algılama fiilleri}

İşitme ile ilgili algılama fiiller başlı̆̆ içerisinde toplam 6 fiil yer almaktadır. Fiillerin çoğu "Özbek Tilinin İzåhli Frazeologik Lugäti” adlı sözlükten tespit edilmiştir.

tinglä- "dikkatlice dinlemek" (ÖTíL, s. 100), tingşä- "tüm dikkatiyle dinlemek, kulağını açmak" (ÖTILL, s. 100), eşit- "dinlemek" (TÖS, s. 159), qulåk ås- "dikkatle dinlemek. (ÖTİFL, s. 293), qulåk ber- "dinlemek. (ÖTİFL, s. 292), qulåk sål- “dinlemek” (ÖTİFL, s. 293).

\subsubsection{Tatma ile ilgili algılama fiilleri}

Tatma ile ilgili algılama fiillerine ait toplam 8 fiil tespit edilmiştir. Tespit edilen fiillerin büyük kısmına “Özbek Tilinin İzåhli Lugääti” adlı sözlükten ulaşılmıştır.

ye- "yemek, tadına bakmak" (ÖTİL, s. 9), tot- "tatmak" (TÖS, s. 562), tatib kor- "tatmak" (TÖS, s. 562), tati- "tatmak" (TÖS, s. 562), istemål qil- "yemek, içmek” (ÖTİL, s. 236), tämäddi qil"atıştırmak, hafif yiyecekler yemek" (ÖTİL, s. 654), tåt- "1. biraz yemek, içmek, tatmak 2. yemek, içmek 3. tadına bakmak, denemek" (ÖTíL, s. 158), tåtin- "az yemek, içmek, tadına bakmak" (ÖTíL, s. 158).

\subsubsection{Koklama ile ilgili algılama fiilleri}

Koklama ile ilgili algılama fiilleri başlığına ait toplam 2 fiil tespit edilmiştir. Bu fiiller "Özbek Tilinin İzåhli Frazeologik Lug̈ätı” adlı sözlükten alınmıştır.

hidlä- "koklamak" (ÖTİL, s. 526), iskä- "koklamak" (ÖTİL, s. 230).

\subsubsection{Dokunma ile ilgili algılama fiilleri}

Dokunma ile ilgili algılama fiilleri başlı̆̆ında yer alan 2 fiil de "Türkçe- Özbekçe Sözlük" adlı çalışmadan tespit edilmiştir.

teg- "dokunmak" (TÖS, s. 164), tokin- "dokunmak” (TÖS, s. 164).

\section{Sonuç}

Bu çalışmada 3 kaynaktan yola çıkılarak Özbek Türkçesindeki mental fiiller incelenmiştir. İncelenen eserlerden elde edilen fiillerin sayısı elbette Özbek Türkçesinde yer alan tüm psikolojik durum fiillerinin sayısını gösteremez. Çalışmanın sınırlılığı açısından "Özbek Tilinin İzåhli Lugäti”, “Özbek Tilinin İzåhli Frazeologik Lugäti”, “Türkçe- Özbekçe Sözlük” adlı kaynakların çalışma konusuyla ilgili olarak genel bir durum tespiti açısından yeterli olacağı düşünülmektedir.

Çalışmada ayrıca fiillerinin yanı sıra deyimleşmiş fiillere de yer verilmiştir. Dilin soyut anlatım yönüne katkı sağlamakta olan deyimleşmiş fiiller arasında mental durumla ilgili olanlar da bulunduğu görülmektedir.

\begin{tabular}{|c|c|}
\hline & \\
\hline aları $D$ & d Literatur \\
\hline $\mathrm{Mal}$ & Mahallesi, Mürver Çiçeği Sokak, No:14/8 \\
\hline Kadıköy & STANBUL / TURKEY 34714 \\
\hline $\begin{array}{r}\text { e-posta: edito } \\
\text { tel: }+905057958124,+\end{array}$ & $\begin{array}{l}\text { editor@rumelide.com, } \\
\text { +90 505 7958124, +90 } 216773 \text { o } 616\end{array}$ \\
\hline
\end{tabular}


Taranan eserlerden elde edilen sonuca göre toplam 204 mental fiile ulaşılmıştır. 204 mental fiilden 86’sı “Özbek Tilinin İzåhli Frazeologik Lugäti”, 66’sı “Türkçe- Özbekçe Sözlük” ve 52'si “Özbek Tilinin İzåhli Lugäti” adlı eserlerden tespit edilmiştir.

Toplam 204 mental fiilden 73’ünü "bilişsel fiiller" oluşturmaktadır. 73 "bilişsel fiil”den 33’ü “Özbek Tilinin İzåhli Frazeologik Lugäti”, 25’i “Türkçe- Özbekçe Sözlük”, 15 ’i ise “Özbek Tilinin İzåhli Lugäti” adlı sözlükten alınmıştır.

Tespit edilen 204 mental fiilden toplam 97'si ise "psikolojik durum fiilleri"dir. Psikolojik durum fiillerinden 42'si “Özbek Tilini⿹ İzåhli Frazeologik Lugäti”, 32'si “Türkçe- Özbekçe Sözlük”, 23’ü de "Özbek Tilinin İzåhli Lugäti” adlı kaynaklardan yer almaktadır.

204 mental fiilden 33'ü "algılama ifade eden fiiller"den meydana gelmektedir. Algılama ifade eden fiillerden 14'üne “Özbek Tilinin İzåhli Lugäti”, 11'ine "Özbek Tilinin İzåhli Frazeologik Lugääi”, 8’ine “Türkçe- Özbekçe Sözlük” ten ulaşılmıştır.

"Bilişsel fiiller" toplam 7 alt başlıktan oluşmaktadır. Alt başlıklar içerisinde en çok mental fiilin geçtiği 16 mental fiil ile "anlama ifade eden fiiller", en az mental fiilin geçtiği başlık ise 3 mental fiil ile "tahmin ifade eden fiiller" başlığıdır.

Özbek Türkçesindeki "psikolojik durum fiilleri” ile ilgili olarak verilen alt başlıklardan en az fiilin bulunduğu başlık 3 fiil ile "pişmanlık ifade eden fiiller" en çok fiilin geçtĭgi başlık ise 24 fiil ile "üzüntü ifade eden filler" başlı̆̆ıdır.

Mental fiillerin toplandığı "algılama ifade eden fiiller" başlığında en çok mental fiilin geçtiği alt başlık olan "görme ile ilgili fiiller" başlığında toplam 15 mental fiil bulunmaktadır. En az mental fiilin geçtiği iki başlık bulunmaktadır. Bunlar ikişer mental fiilin bulunduğu "koklama ile ilgili fiiller" ve "dokunma ile ilgili fiiller" başlı̆̆ıdır.

Özbek Türkçesindeki mental fiiller arasında Türkiye Türkçesinde de kullanılan ortak mental fiiller de bulunmaktadır. Özbek Türkçesindeki mental fiillerden Türkiye Türkçesinde ortak kullanılan toplam 45 mental fiil tespit edilmiştir. Bu fiillerden 19'u "psikolojik durum fiilleri”, 17'si “bilişsel fiiller", 9'u da "algılama ifade eden fiiller" den oluşmaktadır. Özbek Türkçesi ile Türkiye Türkçesinde ortak kullanılan mental fiillerden en çok "psikolojik durum fiilleri” ile ilgili olduğu görülmektedir. 


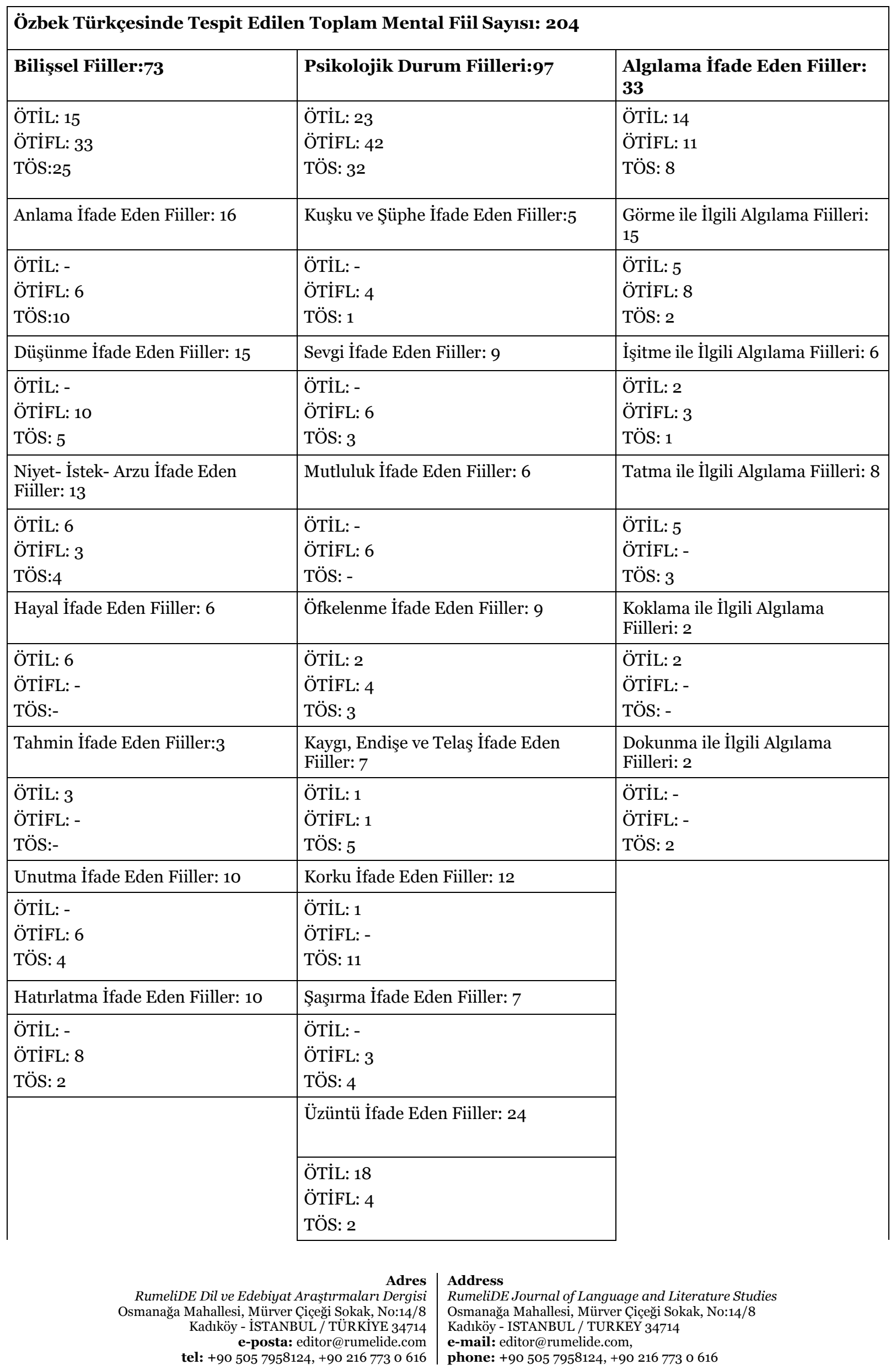




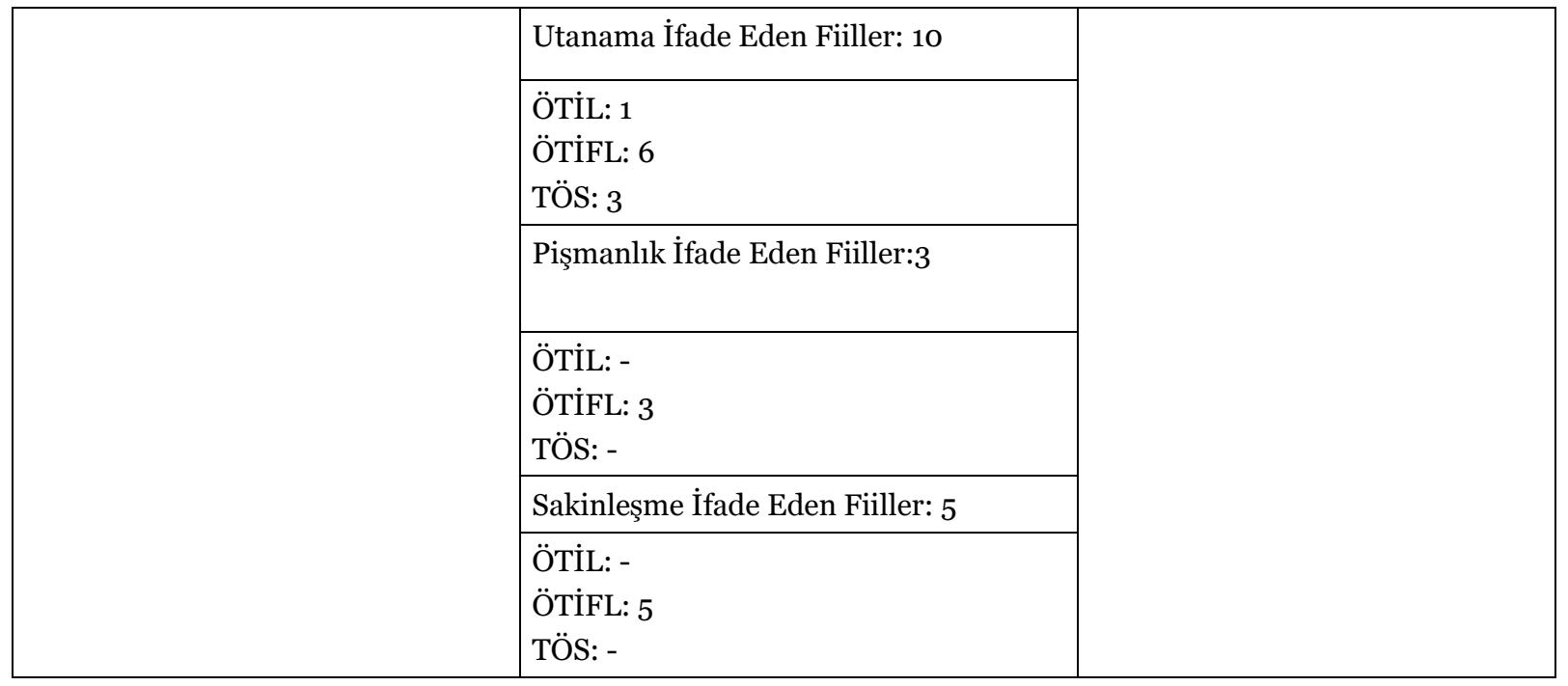

Tablo 1. Özbek Türkçesindeki mental fiillerin dağılımı

\begin{tabular}{|c|c|}
\hline \multicolumn{2}{|c|}{ Özbek Türkçesi ve Türkiye Türkçesinde Ortak Olan Mental Fiiller } \\
\hline Özbek Türkçesi & Türkiye Türkçesi \\
\hline angla- (TÖS, s. 40) & anla- (TS, s. 112) \\
\hline idrok et- (TÖS, s. 40) & idrak et- (TS, s. 1047) \\
\hline qamra- (TÖS, s. 319) & kavra- (TS, s. 1244) \\
\hline közini åç- (ÖTİFL, s. 245) & gözünü aç- (ADS, s. 820) \\
\hline äklı yet- (ÖTİFL, s. 29) & aklı bas- (ADS, s. 552) \\
\hline özidän ket- (ÖTİFL, s. 281 & kendini kaybet- (ADS, s. 924) \\
\hline özig̈ä kel- (ÖTİFL, s. 280) & kendine gel- (ADS, s. 922) \\
\hline årzulä- (ÖTİL, s. 136) & arzula- (TS, s. 140) \\
\hline ista- (TÖS, s. 290) & iste- (TS, s. 1104) \\
\hline tilä- (TÖTİL, 94) & dile- (TS, s. 590) \\
\hline åyåg tirä- (ÖTİFL, s. 164) & ayak dire- (TADS, s. 117) \\
\hline häyålgä tål- (ÖTİL, s. 373) & hayale dal- (TADS, s. 221) \\
\hline tähminlä- (ÖTİL, s. 16) & tahmin et- (TS, s. 2114) \\
\hline unut- (TÖS, s. 600) & unut- (TS, s. 2283) \\
\hline unittir- (TÖS, s. 600) & unuttur- (TS, s. 2283) \\
\hline unitil- (TÖS, s. 600) & unutul- (TS, s. 2283) \\
\hline xotirla- (TÖS, s. 252) & hatırla- (TS, s. 957) \\
\hline şubhalan- (TÖS, s. 548) & şüphelen- (TS, s. 2104) \\
\hline täräddutlän- (ÖTİL, s. 673) & tereddüt et- (TS, s. 2197) \\
\hline sev- (TÖS, s. 507) & sev- (TS, s. 1955) \\
\hline $\begin{array}{r}\text { Adres } \\
\text { RumeliDE Dil ve Edebiyat Araștrrmalar Dergisi } \\
\text { Osmanağa Mahallesi, Mürver Ciçeğ Sokak, No:14/8 } \\
\text { Kadıköy - İSTANBUL / TÜRKiYE } 34714 \\
\text { e-posta: editor@rumelide.com } \\
\text { tel: }+90 \text { 505 7958124, +90 } 2167730616\end{array}$ & \begin{tabular}{|l} 
Address \\
RumeliDE Journal of Language and Literature Studies \\
Osmanağa Mahallesi, Mürver Ciçeği Sokak, No:14/8 \\
Kadıköy - ISTANBUL / TURKEY 34714 \\
e-mail: editor@rumelide.com, \\
phone: +90 505 7958124, +90 216773 o 616
\end{tabular} \\
\hline
\end{tabular}




\begin{tabular}{|c|c|}
\hline könil båglä- (ÖTİFL, s. 153) & gönül ver- (ADS, s. 803) \\
\hline åġzi qulågigä yet- (ÖTİFL, s. 203) & ağzı kulaklarına var- (ADS, s. 540) \\
\hline qizi- (TÖS, s. 335) & k1z- (TS, s. 1320) \\
\hline asabiyläş- (ÖTİL, s. 104) & asabileş- (TS, s. 140) \\
\hline hırslan- (TÖS, s. 261) & hurslan- (TS, s. 989) \\
\hline aqlini yoqåt- (ÖTİFL, s. 30) & aklını kaybet- (ADS, s. 556) \\
\hline talaşlan- (TÖS, s. 568) & telâşlan- (TS, s. 2177) \\
\hline irkil- (TÖS, s. 288) & irkil- (TS, s. 1097) \\
\hline hurk- (TÖS, 611) & ürk- (TS, s. 2312) \\
\hline häyråtdä qål- (ÖTİFL, s. 307) & hayret et- (TS, s. 969) \\
\hline cånig̈ä teg- (ÖTİFL, s. 96) & canı burnuna gel- (ADS, s.672) \\
\hline käyfi bozul- (ÖTİFL, s. 125) & keyfi bozul- (TADS, s. 260) \\
\hline özini özi yeb koy- (ÖTİFL, s. 281) & kendi kendini ye- (TADS, s. 257) \\
\hline yergä kirip ket- (ÖTİFL, s. 81) & yerin dibine geç- (ADS, s. 1116) \\
\hline puşäyman bol- (ÖTİL, s. 325) & pişman ol- (TS, s. 1808) \\
\hline puşäyman qil- (ÖTİL, s. 325) & pişman et- (TS, s. 1808) \\
\hline bok- (TÖS, s. 66) & bak- (TS, s. 205- 206) \\
\hline közdän keçir- (ÖTİFL, 133) & gözden geçir- (ADS, s. 808) \\
\hline tinglä- (ÖTİL, s. 100) & dinle- (TS, s. 594) \\
\hline eşit- (TÖS, s. 159) & işit- (TS, s. 1116) \\
\hline kulak ber- (ÖTİFL, s. 292) & kulak ver- (ADS, s. 945) \\
\hline ye- (ÖTİL, s. 9) & ye- (TS, s. 2428) \\
\hline tat- (TÖS, s. 562) & tat- (TS, s. 2153) \\
\hline değ- (TÖS, s. 164) & değ- (TS, s. 542) \\
\hline dokun- (TÖS, 164) & dokun- (TS, s. 616) \\
\hline
\end{tabular}

Tablo 2. Özbek Türkçesi ve Türkiye Türkçesinde ortak olan mental fiillerin dağılımı

\section{Çeviriyazı işaretleri}

ä: açık e (a ile e ünlüsünün arasındaki bir ses)

å: yuvarlak a (a ile o ünlüsünün arasında bir ses)

q: kalın k

y: damak n'si 


\section{Kisaltmalar}

$\begin{array}{ll}\text { ADS } & \text { : Atasözleri ve Deyimler Sözlüğü } \\ \text { ÖTíL } & \text { : Özbek Tilinin İzåhli Lugaäti } \\ \text { ÖTİFL } & \text { : Özbek Tilinin İzåhli Frazeologik Lugäti } \\ \text { s } & \text { :sayfa } \\ \text { TADS } & \text { : Türkçe Atasözleri ve Deyimler Sözlüğü } \\ \text { TÖS } & \text { : Türkçe- Özbekçe Sözlük } \\ \text { TS } & \text { : Türkçe Sözlük }\end{array}$

\section{Kaynakça}

Aksoy, Ö. A. (1988), Atasözleri ve Deyimler Sözlüğü, İstanbul: İnkılâp.

Ayan, E. ve Türkdil, Y. (2015), "Kazak Türkçesinde Dokunma Duyu Fiilleri ve Anlam Zenginliği", International Periodical For The Luanguages, Literature, and History of Turkish or Turkic 2/3, s. 95-114.

Ayan, E. ve Türkdil, Y. (2014), “Anlam Bilimi Açısından Kazak Türkçesinde Görme Duyu Fiilleri”, Uluslararası Sosyal Araştırmalar Dergisi, 7 (35), s. 26-41.

Biray, N. (2006). "Kazak Şivesi ve Denizli Ağzında Kök Halindeki İdrak Fiillerinde Anlam Farklılaşmaları", Uluslararası Denizli ve Çevresi Tarih ve Kültür Sempozyumu Bildirileri, PAÜ Fen Edebiyat Fakültesi Tarih Bölümü Yayınları:1, Sempozyum Dizisi:1, Cilt II, Denizli.

Çeçen, R. A. (2002), "Duygular İnsan Yaşaminda Neden Vazgeçilmez ve Önemlidir?”, Çukurova Üniversitesi Sosyal Bilimler Dergisi, c.:9, Sayı: 9, s. 164- 170.

Çotuksöken, Y. (2004), Türkçe Atasözleri ve Deyimler Sözlüğ̈̈, İstanbul: Toroslu Kitaplı̆̆ı.

Hirik, E. (2017), “Türkiye Türkçesi Duyu Fiillerinde Anlam ve Kelime Sıklı̆̆ı İlişkisi”, SUTAD, 41, s. 53-74.

Hirik, E. (2018), Türkiye Türkçesinde Mental Füiller. Ankara: Türk Kültürünü Araştırma Enstitüsü.

Kamchybekova, A. K. (2011), "Kırgız Türkçesinde Duyu Fiilleri", ODÜ Sosyal Bilimler Enstitüsü Dergisi 2/3, s. 87-102.

Kamchybekova, K. (2013), "Kırgız Türkçesinde Tat Alma Duyu Fiilleri (Sözcüksel Anlam Bilimi Açısından Bir Deneme)", Türk Dünyası Dil ve Edebiyat Dergisi, 35, s. 9-22

Kamchybekova, K. (2010), Kırgız Türkçesinde Duyu Fiilleri, Doktora Tezi, Ankara: Ankara Üniversitesi.

Kamchybekova, K. (2011), "Duyu Fiillerinde Anlamsal Özellikler Üzerine”, Modern Türklük Araştırmaları Dergisi, 8/2, s. 22-35.

Özbek Tilinin İzåhli Lugaäti (2006), Tåşkent: Dävlåt İlmiy Näşriyåti.

Özeren, M. ve Alan, İ. (2018), "Kırgız Türkçesinde Mental Fiiller”, Atatürk Üniversitesi Türkiyat Araştırmaları Dergisi, 61, s. 203-224.

Rahmatullaev, Ş. (1978), Özbek Tilinin İzåhli Frazeologik Lugäti. Tåşkent: Oqituvçi Näşriyåti.

Şahin, S. (2012), "Mental Fiil Kavramı ve Türkmen Türkçesinde Mental Fiiller", Uluslararası Türkçe Edebiyat Kültür Eğitim Dergisi 1/4, s. 45-62.

Türkçe Sözlük (1988), Ankara: Türk Dil Kurumu.

Yaylagül, Ö. (2005), "Türk Runik Harfli Metinlerde Mental Fiiller", Modern Türklük Araştırmaları Dergisi, 2/1, s. 17-51.

Yaylagül, Ö. (2011), "Türkiye Türkçesindeki Duygu Fiilleri”, Modern Türklük Araştırmaları Dergisi, 7 (4), s. 100-111.

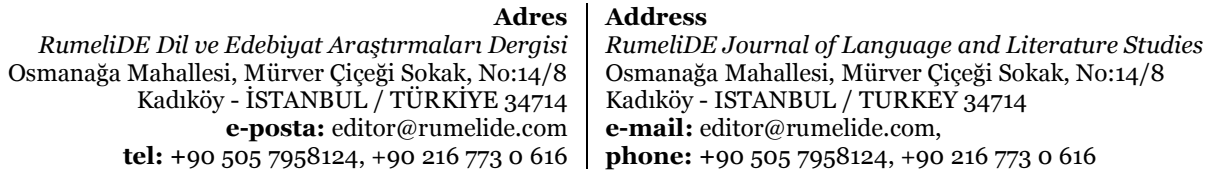


Yegin, A. (2019), Mental Fiil Kavramı ve Şeyyâd Hamza'nın Yusuf u Zeliha Mesnevisinde Mental Fiiller, Bartın Üniversitesi Edebiyat Fakültesi Dergisi, c.: 4, Sayı: 9, s. 51- 74.

Yıldı, H. (2017), "Eski Uygurcada Göz Fiilleri" JOTS, 1/1, s. 145-213.

Yıldız, H. (2018), “Atebetü'l-Hakayık’ta Algı Fiilleri”, Karadeniz Araştırmaları, XV/6o, s. 163-181.

Yıldız, H. (2019), “Eski Uygurcada Bellek Fiilleri”, Türkbilig, 37, s. 21-34.

Yıldız, H. (2020), Eski Uygurcada Mental Fiiller Arası Geçişler Üzerine Notlar, Gazi Türkiyat, S. 26, s. 105- 125 .

Yusupoava, N. (2018), “Türkçe- Özbekçe Sözlük”, Ankara: Türk Dil Kurumu. 